\title{
State of Remittance and Balance of Payment in Nepal
}

\author{
Gorakh Raj Ojha*
}

\begin{abstract}
Foreign employment of Nepali workers is viewed as a potential source of foreign exchange and a way to reduce poverty. This article, on the basis of time series trend of remittance inflow to Nepal, aims at shedding light on the relative importance and contribution of remittance to the BOP of Nepal. It is also tried to spell out problems and remedial measures relating to foreign employment of Nepali workers.
\end{abstract}

Keywords: Remittance, balance of payment, relationship, ratios, Nepal.

\section{INTRODUCTION}

Balance of Payments (BOP) of a country is a systematic record of all its economic transactions with the rest of the world. Alternatively, the BOP is a statistical statement of the country's economic relation with other countries showing its trading position, changes in its net position as foreign lender or borrower and changes in the country's reserve holdings taken place during a given period of time, usually, during a fiscal year. The BOP account consists of three sub-accounts, viz. Current account, Capital account and Financial account. Current account keeps the record of trade in goods, services and transfer payments. It has two sides of trade in goods imported and exported. Nepal's import of goods has historically been much higher than its export that has been creating large deficit in trade account each year.

Trade in services include flow of payments and receipts on freight, travel, banking, insurance, transport communication and other miscellaneous payments, Some years ago, inflow of receipts from abroad to Nepal under travel heading was significantly larger than its outflow that resulted in net surplus in the trade in services. But since 1990, Nepal is bearing an increasing deficit in this item owing to an increasing trend of Nepali students going abroad for higher level study and tourists using foreign airlines to fly to and from Nepal . wage-income and investment-income are two other items in the current account . The amount of money that the Nepali residents bring home from their short-term job abroad is an inflow under this heading while amount of money taken away by foreigners earned from similar jobs in Nepal is an outflow. Investment-income refers to the amount of money earned in the form of interest and dividend and received from investment made abroad by Nepali citizens and institutions. Ordinarily, the residents of Nepal are not allowed so far to invest capital abroad, but Nepal Rastra Bank (NRB) and commercial banks of Nepal can make investment in foreign securities out of their foreign exchange holdings. Outflow under this heading includes interest paid on loans taken by Nepali citizens from abroad and dividends taken out by foreign investors from Nepal. Nepal has been in deficit in this heading for a long period of time.

\footnotetext{
${ }^{*}$ Mr. Ojha is Associate Professor of Economics, Prithvi Narayan Campus, T.U., Pokhara.
} 
Transfer payments are another headings of current account under which transfer of capital include foreign transfers received by the Government of Nepal (GON) and various institutions of Nepal. Foreign money (remittance) sent to Nepal by Nepali workers working abroad, pensions received by the foreign retired Nepalese etc and similar transfer payments made by Nepal to foreign workers working in Nepal. Since the tendency of Nepali youths to go abroad for job has been increasing over years, the remitted money has been a considerable contribution to inflow of capital under transfer payments that has been creating a net surplus and has helped in shunning off large trade deficit.

Another component of the BOP account is the capital account which includes capital transfers and acquisition and disposal of non-financial assets. In case of Nepal the inflow and outflow of capital in this account are substantially small. Financial consists of foreign direct investment (FDI), other investment (OI), and foreign exchange reserves (FER) and other related items. The inflow of FDI and foreign loan to Nepal is very small.

\section{The BOP Position}

\section{ANALYSIS AND DISCUSSION}

The aggregate BOP position of a country is assessed on the basis of its components as described above. If the total inflow of payments has exceeded $t$ the total outflow of payments in a given year, the country is said to be in BOP surplus which causes increase in the country's foreign exchange reserves . Conversely, if the outflow of payments is in excess of inflow in a year the country' BOP is said to be in deficit which causes depletion in the country's foreign exchange reserves. Since the country's aggregate BOP account keeps record of all inflow and outflow of payments made during a year the overall BOP position of the year reflects the changes occurred in the net foreign assets of the country. Negative sign before the BOP figure implies decrease in foreign assets (increase in the country's liability to foreigners) and the positive sign before the BOP figure indicates increase in foreign assets or decrease in foreign liability.

\section{Remittance from Foreign Employment}

Nepal, after becoming a member of the UNO in 1955 , extended its cordial relationship with the rest of the world and rapid pace of globalization paved the way the Nepalese workers to go abroad for employment and with advent of 1990 thousands of Nepali workers began to go abroad for employment and sending money home. The amount of remittance received by Nepal in 1975/76 was Rs.231.3 million which rose by twice in 1985/86. Nepal received Rs. 292.6 million from abroad in the form of remittance which galloped up to Rs.25,501.4 million in 2002/03. Since 1990 thousands of Nepali workers have been rushing to foreign countries, specially to the Arabian countries, for employment and thousands of Nepali youths go across the border to India for temporary employment as there no visa restriction for India. According to the Department of Labor (GON) more than 55000 Nepali youths had gone to foreign countries other than India in 2000/01 This number rose to 241 thousand in 2007/08 and it further increased to 325 thousand in the year 2008/09. The amount of remittance received by Nepal in 2000/01 was Rs. 42.68 billion and in the first six months of 2007/08 this amount rose to Rs. 57.06 billion while in first six months of 2008/09 it increased to Rs. 94.3 billion which registered a growth rate of 65.3 percent. 
Albeit, an ever increasing volume of export trade is a reliable source of foreign exchange and capital inflow for a growing economy like Nepal but owing to various inside and outside factors the Nepalese export trade has remained sluggish since years ago. However, the increasing inflow of remittance is contributing to maintain a bit satisfactory BOP position of Nepal. Remittance money is contributing about half of the volume of foreign exchange earned by tourism and one fifth part of Nepal's total export trade (NRB 2062). Remittance has also helped in maintaining a stable exchange rate of the Nepali currency (Rupee) and economic stability. The facts mentioned above have been presented in the following schedule and graphs.

Table 1: Aggregate Ratios (percentage)

\begin{tabular}{|l|c|c|c|c|c|c|c|c|c|c|}
\hline \multicolumn{1}{|c|}{ Year } & $\mathbf{2 0 0 0 / 0 1}$ & $\mathbf{2 0 0 1 / 0 2}$ & $\mathbf{2 0 0 2 / 0 3}$ & $\mathbf{2 0 0 3 / 0 4}$ & $\mathbf{2 0 0 4 / 0 5}$ & $\mathbf{2 0 0 5 / 0 6}$ & $\mathbf{2 0 0 6 / 0 7}$ & $\mathbf{2 0 0 7 / 0 8}$ & $\mathbf{2 0 0 8 / 0 9}$ & $\mathbf{2 0 0 9 / 1 0}$ \\
\hline $\begin{array}{l}\text { Remittance/ } \\
\text { GDP ratio }\end{array}$ & 10.7 & 10.5 & 11.5 & 11.8 & 12.2 & 15.6 & 14.2 & 18.0 & 18.7 & 19.1 \\
\hline $\begin{array}{l}\text { Remittance/ } \\
\text { Exchange } \\
\text { earnings ratio }\end{array}$ & 30.0 & 35.0 & 39.5 & 39.6 & 43.0 & 49.8 & 50.1 & 50.0 & 55.3 & 56.6 \\
\hline $\begin{array}{l}\text { Export/ } \\
\text { Exchange } \\
\text { earnings ratio }\end{array}$ & 35.0 & 34.7 & 36.1 & 36.5 & 36.8 & 32.3 & 30.1 & 24.2 & 22.3 & 21.4 \\
\hline
\end{tabular}

Source: NRB, Reports of various years and Ministry of Finance, Economic Surveys of various years.

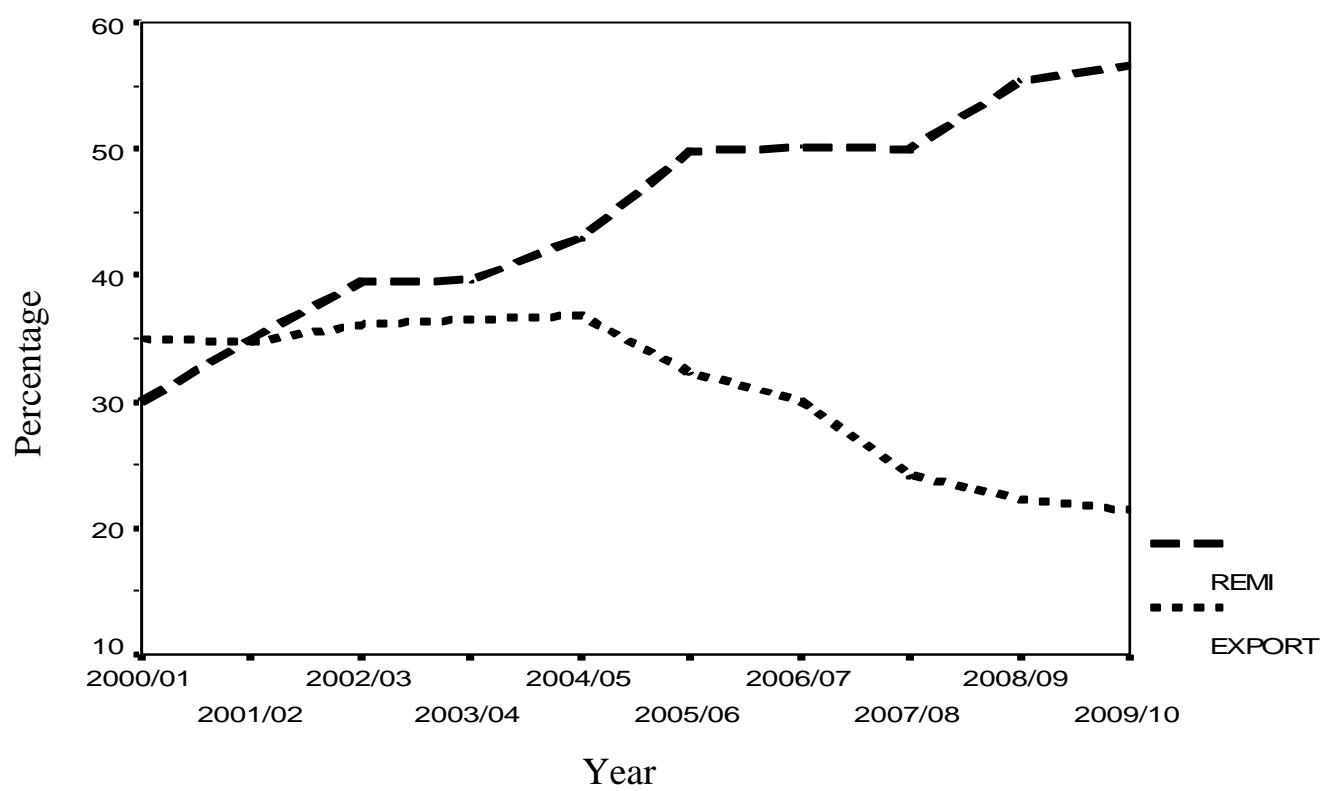

Figure 1: Trends of Remittance and Export over the years 


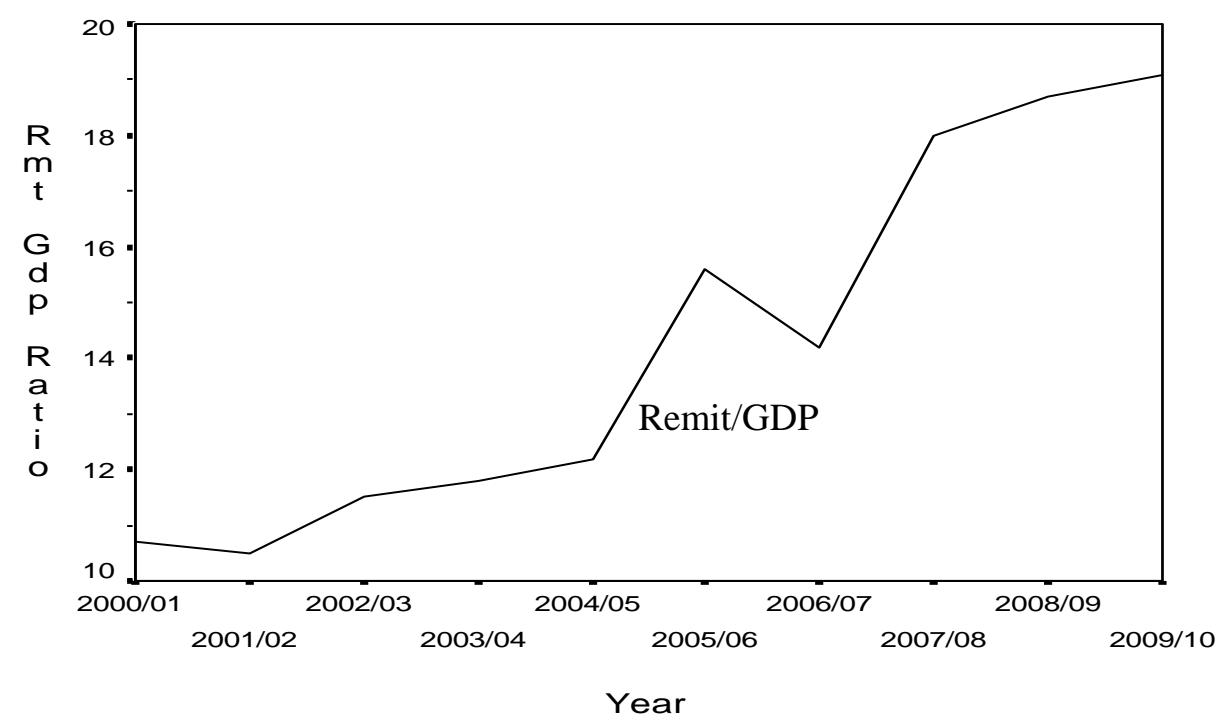

Figure 2: Remittance /GDP Ratio

The above schedule and figure 1 show that some years ago export trade was the principal source of Nepal's foreign exchange earning though it was not sufficient, but in recent years inflow of remittance has taken its place In the year 2000/01 the contribution of remittance to Nepal's foreign exchange earning was approximately $30 \%$ which increased to $50.8 \%$ in $2007 / 08$ and the share of remittance in Nepal's total foreign exchange earnings rose to $54.8 \%$ in the first six of 2008/09. This growth rate of remittance sheds light on its importance for which an import based economy. Moreover, remittance has contributed a great deal to the growth rate of GDP of Nepal. The first row of the above schedule and figure 2 has shown that the ratio of remittance to Nepal's GDP is increasing since some years here. In $2000 / 01$ this ratio was $10.7 \%$ which increased to $17.4 \%$ in $2007 / 08$ and again to nearly $19 \%$ in 2008/09 (NRB, 2068). This ratio reached to $18.7 \%$ in $2008 / 09$ and $19.1 \%$ in $2009 / 10$.

\section{Global Employment Tendency}

Prior to 2005 the time series of labor employment in most the countries, especially in the USA, Japan, Malaysia, south Korea and the gulf-countries was increasing where several Nepali migrant workers were getting job. But after 2006/07 an economic havoc overlapped the smoothly going investment and employment trend in those countries owing to which they cut off the demand for foreign workers in a large scale. The global recession influenced Nepal too. According Department of Labor (GON), more than 23 thousand workers had left Nepal for foreign employment in 2009 but this shunned down to 17 thousand in the following year, since Malaysia , South Korea and other gulf-countries are major destinations for the Nepali workers the recessionary wave experienced by these countries compelled them to cut off labor employment. As a consequence thousands of Nepali migrant workers working abroad lost their jobs and returned back home. Consequently Nepal's remittance earning squeezed and Nepal's BOP ran down to deficit at the end of 2011 (NRB 2011). However from 2012 the economic scenario showed improvement to some extent and the outflow of Nepali migrant laborers is increasing again. But economists have indicated that the US fiscal cliff and the financial crisis in some European countries may again push them to recession. 


\section{CONCLUSION AND SUGGESTIONS}

On account of the lack of employment opportunities in Nepal thousands of Nepali workers have going abroad for employment and they sending remittance home in foreign currencies which is taken for granted as supportive to Nepal's BOP on the hand and the remittance has improved the socio-economic status of the workers' families on the other. Most of the Nepali workers are unskilled and professionally untrained because of which they do not reasonable wages on the one side and they have to do highly risky jobs abroad on the other side. Furthermore, there is no guarantee of job, wages and other facilities as contracted before. Many of them have lost their life and property in the past. So far the destination of the migrant Nepali workers is confined to a few countries which may be risky in the sense that if ever a deep recession occurs in these countries, the Nepali workers working there would lose their jobs.

Nepali workers job abroad and send money home. This is a happy aspect of foreign employment. Thousand of Nepali workers have gone abroad and thousand of them are in the pipeline. Because of these persistent outflow young workers several plots of formerly cultivated land have remained uncultivated and barren. The workers who have retired from abroad have not had any productive skill. More over those who earned money abroad have purchased land and houses in the urban areas. Several villages in the hilly areas have become empty of human beings or of youths. Even the educated and skilled manpower of Nepal is working abroad. This persistently increasing muscle and brain drain seemingly indicates the grim gloomy future of Nepal.

Keeping the above facts in mind, Nepal should formulate an appropriate foreign employment policy such that foreign employment of Nepali workers can be diversified to several countries having high employment potentialities with high remunerations. Professional training and skill building programs can be framed and implemented by the Department of Labor in different parts of the country. Foreign employment, in fact, is not a long-run solution to the unemployment problem. It is, therefore, necessary to create a immense opportunities of employment within the country. Export trade can be expanded and diversified and the tourism sector can be developed in the country's potential areas that may fetch enough foreign exchange.

\section{REFERENCES}

Nepal Rastra Bank, (2011). Annual Reports 2002/03 to 2010/11. Kathmandu: Author.

Nepal Rastra Bank (2011). Macroeconomic Indicates of Nepal, 2007/08 and 2009/10. Kathmandu.

Ministry of Finance (2068 BS). Economic Survey, 2065/66 and 2067/68 B.S. Kathmandu: Author.

Central Bureau of Statistics (2011). Statistical Pocket Book 2009/10. Kathmandu: Author.

Central Bureau of Statistics (2009). Statistical Year Book 2008/09, Kathmandu. 